\title{
HILGARDIA
}

A Journal of Agricultural Science Published by

the California Agricultural Experiment Station

\section{NITIDULID BEETLES INFESTING CALIFORNIA DATES}

\author{
DAVID L. LINDGREN and \\ LLOYD E. VINCENT
}

UNIVERSITY OF CALIFORNIA • BERKELEY, CALIFORNIA 
Four predominant species of nitidulid beetles infest dates in the Coachella ValleyCarpophilus dimidiatus (Fabricius), C. hemipterus (Linnaeus), Haptoncus luteolus (Erichson), and Urophorus humeralis (Fabricius). From 1947 to 1951 inclusive, it was found that during the season dates ripen 75 to 90 per cent of the insects present in dates examined were C. dimidiatus, C. hemipterus being second most abundant. Catches by traps baited with fermenting dried peaches from March to July inclusive were predominantly $\mathrm{C}$. dimidiatus, while $\mathrm{H}$. luteolus ranked second.

To develop from egg to adult at $80^{\circ} \mathrm{F}$, it required:

11.9 days for Haptoncus luteolus;

15.8 days for Carpophilus hemipterus;

20.6 days for Urophorus humeralis;

20.7 days for $C$. dimidiatus.

At $90^{\circ} \mathrm{F}$ it required:

9.6 days for $\mathrm{H}$. luteolus;

12.4 days for $C$. hemipterus;

14.7 days for $C$. dimidiatus;

16.5 days for $U$. humeralis.

It required a longer exposure to kill the larvae of Urophorus humeralis, at $109^{\circ}$ and $115^{\circ} \mathrm{F}$ at 10,50 , and 90 per cent relative humidities, than it did to kill the adults of Carpophilus hemipterus, $\mathrm{C}$. dimidiatus, and $\mathrm{U}$. humeralis. At $120^{\circ} \mathrm{F}$ this trend was not apparent. Of the adults, $U$. humeralis was the most susceptible to exposure to high temperatures regardless of humidity. At $109^{\circ} \mathrm{F}$ it required a longer exposure to kill the adults of $C$. hemipterus, $C$. dimidiatus, $U$. humeralis, and larvae of $U$. humeralis at 90 per cent relative humidity than it did at 10 per cent. At $120^{\circ} \mathrm{F}$ the reverse was true.

Ethylene chlorobromide and ethylene dibromide appear to be more effective than methyl bromide as fumigants of eggs of Urophorus humeralis. Under similar conditions it required six times as much methyl bromide as ethylene dibromide or ethylene chlorobromide to kill 100 per cent of $U$. humeralis eggs. Ethylene dibromide proved a more effective fumigant against nitidulid larvae than either ethylene chlorobromide or methyl bromide. Ethylene dibromide is as effective to adults of all four species as ethylene chlorobromide or methyl bromide, or even more so. It required a longer period after fumigation with ethylene chlorobromide and ethylene dibromide for the insects to die than with methyl bromide. Seven days after treatment, dates still contained 80 to 85 per cent of the total bromide initially absorbed from methyl bromide fumigation, 44 to 54 per cent of that from ethylene dibromide fumigation.

In laboratory and field experiments it was found that lindane, chlordane, aldrin, dieldrin, heptachlor, parathion, and malathon not only had high initial toxicity to the various species but also an effective residual toxicity. Chlordane and lindane applied as dusts occasionally imparted an off-flavor to dates. Extensive field experiments indicate that a 5 per cent malathon dust applied 3 to 4 weeks before picking is very effective in reducing live beetles and infested dates in the bunch.

Benzene hexachloride, dieldrin, and chlordane, at rates of $1 \frac{1}{2}$ to 2 pounds per acre dusted onto the surface of the soil and raked in, prevented a high percentage of the beetles from emerging from the treated soil. Indications are that some of these soil treatments may remain effective as long as 1 to 2 months under Coachella Valley conditions. 


\section{$\begin{array}{llllllll}H & \text { I } & \text { L } & G & \text { A } & \text { R } & \text { D I A } & \text { A }\end{array}$}

A Journal of Agricultural Science Published by

the California Agricultural Experiment Station

\begin{tabular}{lll}
\hline VoL. 22 & MARCH, 1953 & No. 2 \\
\hline
\end{tabular}

\section{NITIDULID BEETLES INFESTING CALIFORNIA DATES}

\section{DAVID L. LINDGREN ${ }^{2}$ and LLOYD E. VINCENT"}

The Coachei.l.. Valiey in the southern California desert region has suitable temperatures for growing dates, producing all but 10 per cent of the United States crop. This crop rose from 1 million pounds in 1926 to 33 million pounds in 1946, just twenty years later (Nixon, 1951). In 1924 a total of 546 acres was planted to dates; in 1950 this had increased to 5,114 acres, of which 4,140 acres were bearing (Byrd and Blair, 1951).

In the same period a tremendous increase took place in acreage of other (rops grown in the date-producing region. Irrigation projects now being completed along the lower Colorado River are resulting in an even greater expansion of agriculture in this area.

Nitidulid beetles also find the Coachella Valley temperature suitable for rapid growth and reproduction except for a few winter months. Because of beetle infestation all dates are fumigated before entering the packing house. This necessitates the building of fumigation chambers.

Under conditions of severe infestation, grading costs mount because of the added time necessary to segregate the infested dates from the sound ones. Although the larvae and adults feed directly on the fresh and dried fruit, the loss due to the amount of fruit actually consumed is insignificant in comparison with the loss due to the presence of excreta, larvae, adults, and the moulting skins in and on the infested dates. In many instances these dates are very difficult to segregate because there is no visible indication that the insects or their remains may be in the seed cavity. These are termed "hidden culls" by the industry.

The beetles also serve as mechanical carriers of mold and souring organisms, which cause additional fruit spoilage. In 1945, a year of abnormally high humidity and rainfall, one half to three fourths of the date crop was lost because of molds, souring, and beetle infestation (Barnes and Lindgren, 1946 ).

This paper is concerned with the four species of beetles that predominate on dates in the Coachella Valley. The four species, closely related members of the family Nitidulidae, are the corn-sap beetle, Carpophilus dimidiatus (Fab.); the dried-fruit beetle, C. hemipterus (Linn.)-also called fig- or two-spotted beetle; the pineapple beetle, Urophorus humeralis (Fab.); and the yellowish nitidulid, Haptoncus luteolus (Er.).

\footnotetext{
' Received for publication April 16, 1952.

" Entomologist in the Experiment Station, Riverside.

" Prineipal Laboratory Technician, Citrus Experiment Station, Riverside.
} 


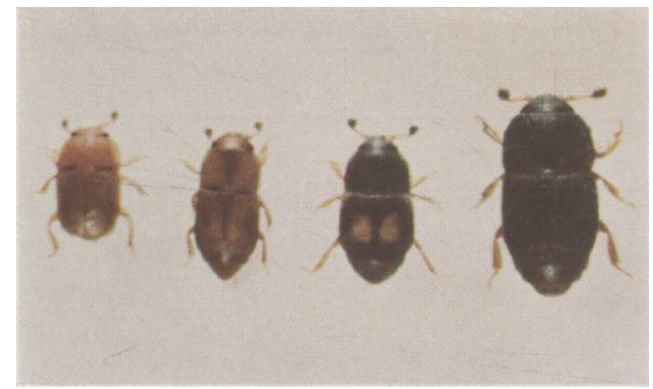

Fig. 1. Adults of four species of nitidulid beetles found infesting dates. Right to left: Urophorus humeralis (F.), Carpophilus hemipterus (L.), Carpophilus dimidiatus (F.), and IIaptoncus luteolus (Er.). 


\section{LITERATURE REFERENCES}

Very few literature references can be found which discuss the biology and pconomic significance of nitidulidae infesting dates in the Coachella Valley. In 1913, Popenoe found that in Arizona a minute beetle, Carpophilus dimidiatus, caused trouble of the same kind as that due to moths. Essig in 1915 found that the dried-fruit beetle, C. hempiterus, was very common throughout California, and because of its attacks on fresh, ripe, and dried fruits, it was a source of anxiety to fruit growers as well as fruit packers and grocers.

Stickney (1924) observed that five species of beetles occur on dates in the Coachella Valley. One of these, Carpophilus hemipterus, attacks the dates as soon as they are mature, preferring those that are soft and juicy. These beetles deposit few or no eggs in fresh fruit, but find sour or decaying dates, especially those lying on the ground beneath the trees, an ideal environment and continue to breed in them slowly all winter.

Lindgren, Bliss, and Barnes (1948) made essentially the same observation in a 3-year study (1945-47), concluding: "No insects were found in soil having no dates present on the surface, whereas many were found where the overlay of decaving dates was heavy."

Streets (1933) found that the decayed tissues (referring to heart rot) attracted a small beetle, 3 to $4 \mathrm{~mm}$ long (Carpophilus hemipterus), which feeds on decaying citrus fruits and dates and is known by the name of "soul" bug" or "fruit beetle."

Barger (1940) states, "Dates attract small beetles, chiefly the dried-fruit beetle, and moths, including the raisin moth and the Indian meal moth."

Barnes and Lindgren $(1946,1947)$ found at least four species of beetles present on dates in the Coachella Valley, with two species predominantCarpophilus hemipterus and $C$. dimidiatus. The adults may live as long as 6 months to a year, and females may produce from 500 to 1,000 eggs each. The beetles are strong and active fliers, flights of $21 \%$ miles having been recorded.

\section{SPECIES OF NITIDULIDAE INFESTING DATES IN THE COACHELLA VALLEY}

Figure 1 shows the four species of nitidulids that predominate in the ('oachella Valley. The following brief descriptions of them are adapted from Parsons (1943).

Carpophilus dimidiatus, commonly known as the "cornsap beetle," is oblong, feebly shining, in color varying from black with a reddish tinge to brownish-yellow, with the elytra always paler-length $2.0-3.5 \mathrm{~mm}$. A number of variations of this species have been described. Parsons lists three forms that are cosmopolitan and intergrade; thus he thinks it best to make them all one variable species. This species occurs in all tropical and temperate parts of the world. In the United States it is found at all times of the year from Quebec to Florida, west through Texas and Kansas to California.

Carpophilus hemipterus, commonly known as the "dried-fruit beetle," is oblong, feebly shining, in color black with buff spots on the elytra-length 2 to $4 \mathrm{~mm}$. This species has been carried in foodstuffs all over the world. It 


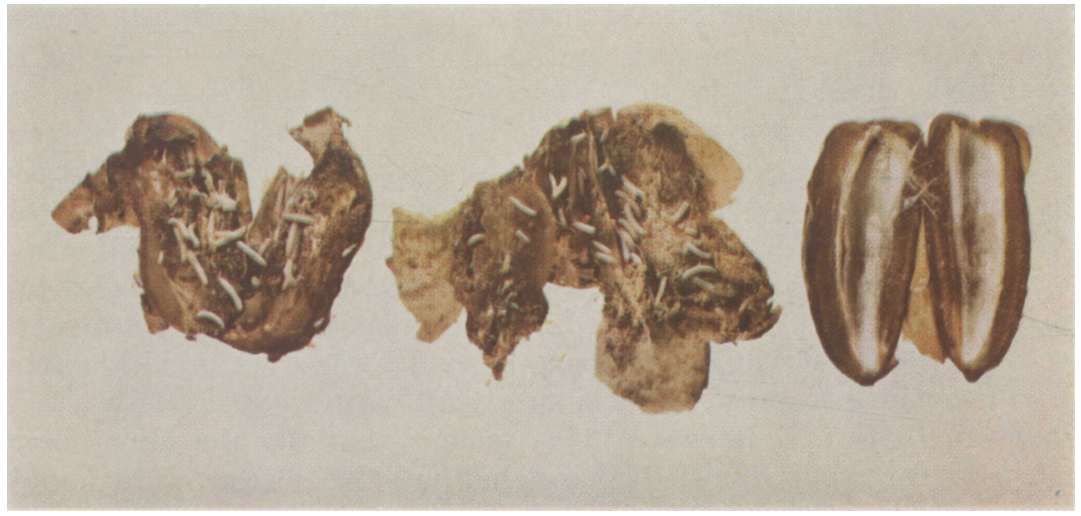

Fig. 2. Larvae of Nitidulidae feeding on dates. Date on extreme right is not infested. 
is particularly abundant in tropical and subtropical regions at all times of the year. In the United States it occurs in Massachusetts, Illinois, Ohio, Kansas, Colorado, and California.

The young larvae of Carpophilus hemipterus, when first hatched, are about $1 / 16$ inch long and white or yellowish in color (fig. 2). Mature larvae attain an average length of about $1 / 4$ inch and are white or yellowish, with the head and tip of the tail amber brown. The body is quite slender. All stages of larvae are very active and move quickly when disturbed. Larvae of the other species of nitidulid beetles found in dates are similar to those of $C$. hemipterus.

Urophorus humeralis is rather broadly oblong oval and brown to black, usually with a small pale spot within the humerus of each elytron. The upper surface of this beetle is strongly shining and polished-length 3.3 to $4 \mathrm{~mm}$, width 1.6 to $1.9 \mathrm{~mm}$. This is the largest of the four species described here, and it is distributed world-wide in foodstuffs. In the United States it is known from Georgia, Florida, California, Arizona, and Utah.

Haptoncus luteolus is oval, slightly oblong, moderately shining, truncate, in color uniformly brownish-yellow-length 2.0 to $2.5 \mathrm{~mm}$. This species is the smallest of the four. Although a few Carpophilus dimidiatus are as small as $H$. luteolus, they are not of the same coloration or shape. This species occurs throughout the year in the United States in California, Arizona, Texas, Alabama to Florida, Tennessee, Ohio, and New Jersey. Recent records in the northern states indicate that $\boldsymbol{H}$. luteolus is being spread by human agency.

\section{RELATIVE ABUNDANCE OF NITIDULID BEETLES}

When the date industry was smaller, and the beetle infestation lighter, losses due to insects were not serious enough to warrant control measures, outside of packing house protection. Within recent years, however, the infestation has become a serious problem calling for control measures in the field.

Stickney (1924) found that the dried-fruit beetle, Carpophilus hemipterus, was predominant in the Coachella Valley, and in the 1930's according to Barnes and Lindgren (1947) it still predominated; but collections made in 1947 through 1951 indicate that the corn-sap beetle ( $C$. dimidiatus) is the dominant species occurring in Deglet Noor dates in the bunches (table 1). During the date-maturing season, July through November inclusive, samples of dates were picked from various localities in the Coachella Valley, cut open, and examined for beetle infestation. In 4 out of 5 years (19471951 inclusive) more than 90 per cent of the beetles in dates picked from the bunches were $C$. dimidiatus, and the fifth year 75 per cent consisted of this species. For some unknown reason $C$. dimidiatus has replaced $C$. hemipterus as the dominant species infesting dates in the Coachella Valley. $C$. hemipterus is at present the second most abundant species.

Because Stickney, Barnes, and Simmons (1950) found fermenting dried peaches to be an especially effective bait for trapping these insects, traps baited with them were put out during the winter and spring of 1950-51 in various localities throughout the date-growing area in the Coachella Valley. Traps were placed out from March to July inclusive, when very little food 
was available. In July the traps were discontinued, because they were competing with natural food sources then becoming available.

Table 2 gives the results of these catches in the different areas. In five of the eight Deglet Noor gardens, Carpophilus dimidiatus was the most abun-

TABLE 1

The Relative Abundance of Four Species of Nitidulid Beetles Found in Deglet Noor Dates Over a 5-Year Period

\begin{tabular}{|c|c|c|c|c|c|c|c|c|}
\hline \multirow{2}{*}{$\begin{array}{c}\text { Year } \\
\text { (July-Nov.) }\end{array}$} & \multicolumn{2}{|c|}{$\begin{array}{l}\text { Carpophilus } \\
\text { dimidiatus }\end{array}$} & \multicolumn{2}{|c|}{$\begin{array}{l}\text { Carpophilus } \\
\text { hemipterus }\end{array}$} & \multicolumn{2}{|c|}{$\begin{array}{l}\text { Urophorus } \\
\text { humeralis }\end{array}$} & \multicolumn{2}{|c|}{$\begin{array}{l}\text { Haptoncus } \\
\text { luteolus }\end{array}$} \\
\hline & Number & $\begin{array}{c}\text { Per cent } \\
\text { of } \\
\text { total }\end{array}$ & Number & $\begin{array}{c}\text { Per cent } \\
\text { of } \\
\text { total }\end{array}$ & Number & $\begin{array}{c}\text { Per cent } \\
\text { of } \\
\text { total }\end{array}$ & Number & $\begin{array}{c}\text { Per cent } \\
\text { of } \\
\text { tatal }\end{array}$ \\
\hline 1947. & 2,416 & 90.6 & 209 & 7.8 & 24 & 0.9 & 18 & 0.7 \\
\hline 1948. & 466 & 94.9 & 25 & 5.1 & 0 & 0.0 & 0 & 0.0 \\
\hline 1949. & 4,370 & 75.4 & 1,300 & 22.4 & 9 & 0.2 & 114 & 2.0 \\
\hline 1950. & 286 & 98.6 & 2 & 0.7 & 0 & 0.0 & 2 & 0.7 \\
\hline 1951. & 1,511 & 99.0 & 13 & 0.8 & 0 & 0.0 & 3 & 0.2 \\
\hline
\end{tabular}

TABLE 2

Relative Abundance of Four. Species of Nitidulid Beetles, in Traps Baited with Fermenting Dried Peaches, in Date Gardens Throughout the Coachella Valley

\begin{tabular}{|c|c|c|c|c|c|}
\hline $\begin{array}{l}\text { Location, garden number, } \\
\text { and date variety }\end{array}$ & $\begin{array}{l}\text { Carpophilus } \\
\text { dimidiatus }\end{array}$ & $\begin{array}{l}\text { Carpophilus } \\
\text { hemipterus }\end{array}$ & $\begin{array}{l}\text { Urophorus } \\
\text { humeralis }\end{array}$ & $\begin{array}{l}\text { Haptoncus } \\
\text { luteolus }\end{array}$ & Total \\
\hline \multicolumn{6}{|l|}{ Indio } \\
\hline No. 1, Khadrawi. & 265 & 11 & 357 & 714 & 1,347 \\
\hline No. 2, Deglet Noor*. & 2,381 & 18 & 68 & 1,201 & 3,668 \\
\hline No. 3, Deglet Noor. . & 1,484 & 78 & 245 & 3,611 & 5,418 \\
\hline \multicolumn{6}{|l|}{ Mecca } \\
\hline No. 1, Khadrawi... & 467 & 126 & 258 & 649 & 1,500 \\
\hline \multicolumn{6}{|l|}{ Thermal } \\
\hline No. 1, Deglet Noor.............. & 838 & 49 & 85 & 372 & 1,344 \\
\hline No. 2, Deglet Noor............... & 818 & 46 & 287 & 569 & 1,720 \\
\hline No. 3, Deglet Noor*. & 826 & 12 & 1,267 & 365 & 2,470 \\
\hline No. 4, Deglet Noor*. & 12,944 & 37 & 2,994 & 1,069 & 17,044 \\
\hline \multicolumn{6}{|l|}{ Indian Wells } \\
\hline No. 1, Deglet Noor. & 975 & 30 & 40 & 324 & 1,369 \\
\hline \multicolumn{6}{|l|}{ Oasis } \\
\hline No. 1, Deglet Noor* & 390 & 14 & 468 & 2,265 & 3,137 \\
\hline
\end{tabular}

* Interset with grapefruit.

dant species. In two Deglet Noor gardens, Haptoncus luteolus was the most abundant, and in one Urophorus humeralis was the dominant species. The population of $C$. hemipterus at this time of year as measured by bait-trap catches appeared to be consistently low.

In the two Khadrawi gardens at Indio and Mecca, Haptoncus luteolus was the most abundant species found in the bait traps. Since bait traps were placed in operation from March through July, this does not necessarily indi- 
eate that $H$. luteolus is the predominant species in the bunches at the time of picking. Khadrawi dates cut and examined for infestation during the ripening season from the same gardens showed that over 75 per cent of the beetles found were Carpophilus dimidiatus, while $H$. luteolus comprised 5 per cent or less of the total insects found infesting dates. This could indicate that $H$. luteolus is more attracted to fermenting peaches than C. dimidiatus; however, observations in the field, during this period, verify the bait-trap collections.

The traps were checked and beetles collected at weekly intervals from early March to the end of July. More beetles were trapped during the month of May than in any other month. During this period, the greatest number of Carpophilus dimidiatus, C. hemipterus, and Urophorus humeralis were trapped in the month of May, while the greatest number of Haptoncus luteolus were trapped in March. The relatively more rapid development of $H$. luteolus at lower temperatures may account for its greater abundance during the winter months.

\section{LIFE-HISTORY STUDIES}

Life-history studies were conducted on the four predominant species of nitidulid beetles infesting dates in the Coachella Valley to determine the length of time required to develop from egg to adult. All tests were conducted in temperature-controlled cabinets.

Eggs were obtained by placing strips of moist green blotting paper in a petri dish containing several beetles of the desired species along with a food

TABLE 3

Length of Development in Days of the Immature Stages of the 4 Species of Dried-Fruit Beetles at Various Temperatures

\begin{tabular}{|c|c|c|c|c|c|}
\hline \multirow{2}{*}{$\begin{array}{l}\text { Insect species and temperature, } \\
\text { deg. } F\end{array}$} & \multicolumn{5}{|c|}{ Time in days } \\
\hline & Egg & Larva & Prepupa & Pupa & Egg to adult \\
\hline \multicolumn{6}{|l|}{ Carpophilus dimidiatus } \\
\hline $65 \ldots \ldots \ldots \ldots \ldots \ldots$ & 4.1 & 15.6 & 11.6 & 17.9 & 49.2 \\
\hline $70 \ldots \ldots \ldots \ldots \ldots \ldots$ & 3.9 & 11.2 & 7.1 & 11.3 & 33.5 \\
\hline $80 \ldots \ldots$ & 2.2 & 7.1 & 4.1 & 7.3 & 20.7 \\
\hline $90 \ldots \ldots$ & 1.6 & 5.1 & 3.1 & 4.9 & 14.7 \\
\hline \multicolumn{6}{|l|}{ Carpophilus hemipterus } \\
\hline $65 \ldots \ldots$ & 4.1 & 13.7 & 8.0 & 16.4 & 42.2 \\
\hline $70 \ldots \ldots$ & 3.0 & 10.4 & 6.3 & 10.7 & 30.4 \\
\hline $80 \ldots \ldots$ & 1.6 & 4.9 & 3.2 & 6.1 & 15.8 \\
\hline 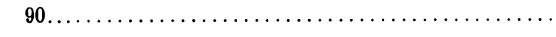 & 1.1 & 4.2 & 2.8 & 4.3 & 12.4 \\
\hline \multicolumn{6}{|l|}{ Haptoncus luteolus } \\
\hline $70 \ldots \ldots \ldots \ldots$ & 3.0 & 9.0 & 6.4 & 7.0 & 25.4 \\
\hline 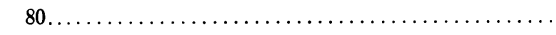 & 1.4 & 5.1 & 2.8 & 2.6 & 11.9 \\
\hline 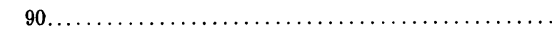 & 1.1 & 3.2 & 2.4 & 2.9 & 9.6 \\
\hline \multicolumn{6}{|l|}{ Urophorus humeralis } \\
\hline $70 \ldots \ldots \ldots \ldots \ldots$ & 3.3 & 10.9 & 8.2 & 11.1 & 33.5 \\
\hline$\ldots \ldots \ldots \ldots \ldots \ldots \ldots \ldots \ldots \ldots$ & 2.0 & 6.3 & 6.0 & 6.3 & 20.6 \\
\hline $90 \ldots \ldots \ldots \ldots \ldots \ldots$ & 1.2 & 5.7 & 4.3 & 5.3 & 16.5 \\
\hline
\end{tabular}


source (small piece of banana). The beetles oviposited in or on the blotting paper. The white eggs, easily discerned on the green blotting paper, were removed and placed on dates. These in turn were placed in petri dishes containing dates (food source) and moist sand (which maintained moisture and provided a place for pupation). Carpophilus dimidiatus and C. hemipterus (the predominant species in the Coachella Valley when dates are maturing) were reared at $65^{\circ}, 70^{\circ}, 80^{\circ}$, and $90^{\circ} \mathrm{F}$; Haptoncus luteolus and Urophorus humeralis at $70^{\circ}, 80^{\circ}$, and $90^{\circ} \mathrm{F}$. The temperatures used are in the range of those occurring in the Coachella Valley during the date-growing season.

TABLE 4

Average Monthly Temperatures at Indio, California, for the 25-YEAR PERIOD 1905-1930*

\begin{tabular}{|c|c|c|c|}
\hline Month & $\begin{array}{c}\text { Average } \\
\text { monthly } \\
\text { temperature }\end{array}$ & Month & $\begin{array}{c}\text { Average } \\
\text { monthly } \\
\text { temperature }\end{array}$ \\
\hline & $\operatorname{deg} . F$. & & deg. $F$. \\
\hline January. . & 54.1 & July.... & 92.1 \\
\hline February.. & 59.6 & August. & 90.8 \\
\hline March.. & 64.7 & September. & 84.9 \\
\hline April... & 71.4 & October. & 74.2 \\
\hline May..... & 78.0 & November... & 63.4 \\
\hline June.... & 87.3 & December..... & 54.7 \\
\hline
\end{tabular}

* Climatological Data, California Section, U. S. Department of Commerce, Weather Bureau. Vol. 9 to 34 1905-1930.

Observations were made twice daily, morning and evening. No attempt was made to distinguish the various larval instars. The prepupal stage was determined as that stage at which the larva left the date and began wandering about the petri dish searching for a place in which to pupate.

The results of these studies are shown in table 3. Haptoncus luteolus exhibited the most rapid development at all temperatures (see table). Carpophilus hemipterus was next in rapidity of development, while $C$. dimidiatus and Urophorus humeralis were almost equal in their rate of development, the former being somewhat more rapid at $90^{\circ} \mathrm{F}$, and both taking 2 to 3 days longer than C. hemipterus to complete their development.

The importance of temperature on the growth and development of these beetles is evident from table 3 . As the temperature drops below $80^{\circ} \mathrm{F}$ the total number of days required to develop from egg to adult increases rapidly. In two of the species (Carpophilus hemipterus and Haptoncus luteolus) it takes about twice as long to reach maturity at $70^{\circ} \mathrm{F}$ as at $80^{\circ} \mathrm{F}$.

Table 4 shows that the average temperatures during June, July, August, and September approximate those at which the development of these beetles is most rapid (namely, above $80^{\circ} \mathrm{F}$ ). The first new source of dates as food for beetles in the date garden at this period is provided by the tree's own natural method of thinning, known as the "June drop," as contrasted with the previous year's drops, which may not have been disked in. It is into these newiy 
dropped dates that the beetles move and begin to build up a population that will eventually infest the dates in the bunches. Since the average egg production for a single female may be as high as 500 to 1,000 eggs laid over a period of several months (Schmidt, 1935), very high populations of beetles may be present in the date garden by the time picking begins. Their activity tends to slow down in October, when the average temperature drops to $74^{\circ} \mathrm{F}$.

The nitidulid beetles pupate in the soil, and in this manner they may overwinter, although adults may be found feeding on dates on the ground near the base of the tree in almost any month. They may also feed on grapefruit that have dropped to the ground and spoiled. Such rotting vegetation serves to feed the overwintering adults, which will help to start the following year's infestation in the date garden.

\section{THERMAL DEATH POINTS OF NITIDULIDAE}

It has been shown (Nixon and Reuther, 1947) that the temperature in the center of the bunch in the fruit zone was $5^{\circ}$ to $10^{\circ} \mathrm{F}$ lower than the outside air temperature during the day. Temperature of the dates at the periphery of the bunch would probably be similar to the outside air temperature.

It is general practice to cover date fruit bunches with waxed crepe-paper tubes, making umbrellalike covers over the bunches to protect them from injury by rain and birds. When the outside air temperature was $105^{\circ} \mathrm{F}$, a temperature of $153^{\circ} \mathrm{F}$ was recorded on the inside and touching that part of a brown-paper cover exposed to direct sunlight (Nixon and Reuther, 1947).

In picking dates it was observed that, on days when the temperature in the early morning was $80^{\circ}-90^{\circ} \mathrm{F}$, many beetles were found in the dates in the bunches, but as the temperature increased to $109^{\circ} \mathrm{F}$ during the middle of the day very few or no beetles were observed there. It was concluded that the temperatures were too high in the date bunches, causing the beetles to search for a cooler place-which they found in the soil since it is general practice during the summer to irrigate date palms every 7 to 14 days.

Because these beetles developed in the presence of high temperatures (although it has been observed that they tend to escape from them), determinations on the thermal death points at various humidities were made. The methods used were similar to those of Oosthuizen (1935). The apparatus consisted of a water bath in which the temperature was controlled within $\pm 0.2^{\circ} \mathrm{F}$. Three 2-quart jars were immersed up to their shoulders in the water bath. Each jar was fitted with a 2-hole rubber stopper, through which were passed a thermometer and a glass tube of $1 / 4$-inch bore. The thermometer bulb and lower end of the glass tube were then inserted into a smaller 2-hole rubber stopper, which in turn fitted into a glass tube 1 inch in diameter, the bottom of this 1-inch glass tube being covered with a fine mesh netting, which served as the bottom of the cage (fig. 3 ). This glass-walled cage was then suspended in the 2-quart jar, in which the humidity was controlled by means of sulfuric-acid solutions (Wilson, 1921). 
After the desired temperature had been reached within the 2-quart jar immersed in the water bath, the test insects were introduced into the insect cage through the $1 / 4$-inch glass tube. This glass tube was then sealed by inserting into it a glass rod slightly longer than the glass tube.

Relative humidities of 10,50 , and 90 per cent were used at temperatures of $109^{\circ}, 115^{\circ}$, and $120^{\circ} \mathrm{F}$. (During the date-ripening season, these temperatures

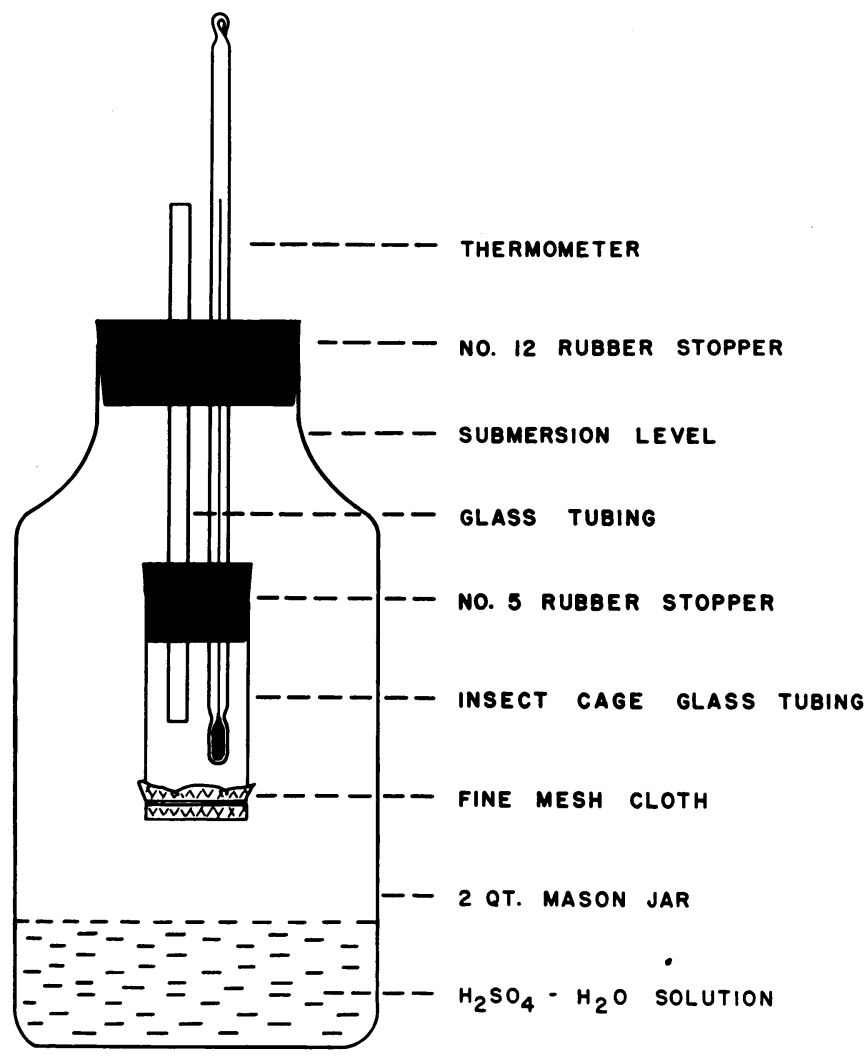

Fig. 3. Diagrammatic sketch of chamber used in determining thermal death points.

are frequently reached in the Coachella Valley.) The insects were kept for 24 hours, after which mortality counts were made. Test insects used were the adults of Carpophilus hemipterus, C. dimidiatus, Urophorus humeralis, and the larvae of $U$. humeralis. Table 5 gives the results of these experiments.

It took longer to kill 50 and 95 per cent of the larvae at $109^{\circ}$ and $115^{\circ} \mathrm{F}$ at all humidities used than to kill adults of all three species. At $120^{\circ} \mathrm{F}$ this relation did not exist.

Of the adults, Urophorus humeralis was the most susceptible to the effects of exposure to high temperature.

At $109^{\circ} \mathrm{F}$ it required a longer exposure to kill the adults and larvae at 90 per cent relative humidity than at 10 per cent. At $115^{\circ} \mathrm{F}$ there was no ob- 
vious difference in the length of time it took to kill these insects at the 10 or 90 per cent relative humidity. At $120^{\circ} \mathrm{F}$ it required a longer time to kill the adults and larvae at 10 per cent than at 90 per cent relative humidity. In other words, a reversal was observed in the effects of relative humidity on thermal death points of these insects.

It appears from table 5 that there are two main causes of death of these insects when they are killed at high temperatures. When the temperature was

\section{TABLE 5}

The Effect of Relative Humidity on the Time Required to Kill 50 Per Cent and 95 PER CENT of THE Adults of Carpophilus hemipterus, C. dimidiatus, Urophorus humeralis, AND THE LARVAE OF $U$. humeralis AT $109^{\circ}, 115^{\circ}$, AND $120^{\circ} \mathrm{F}$

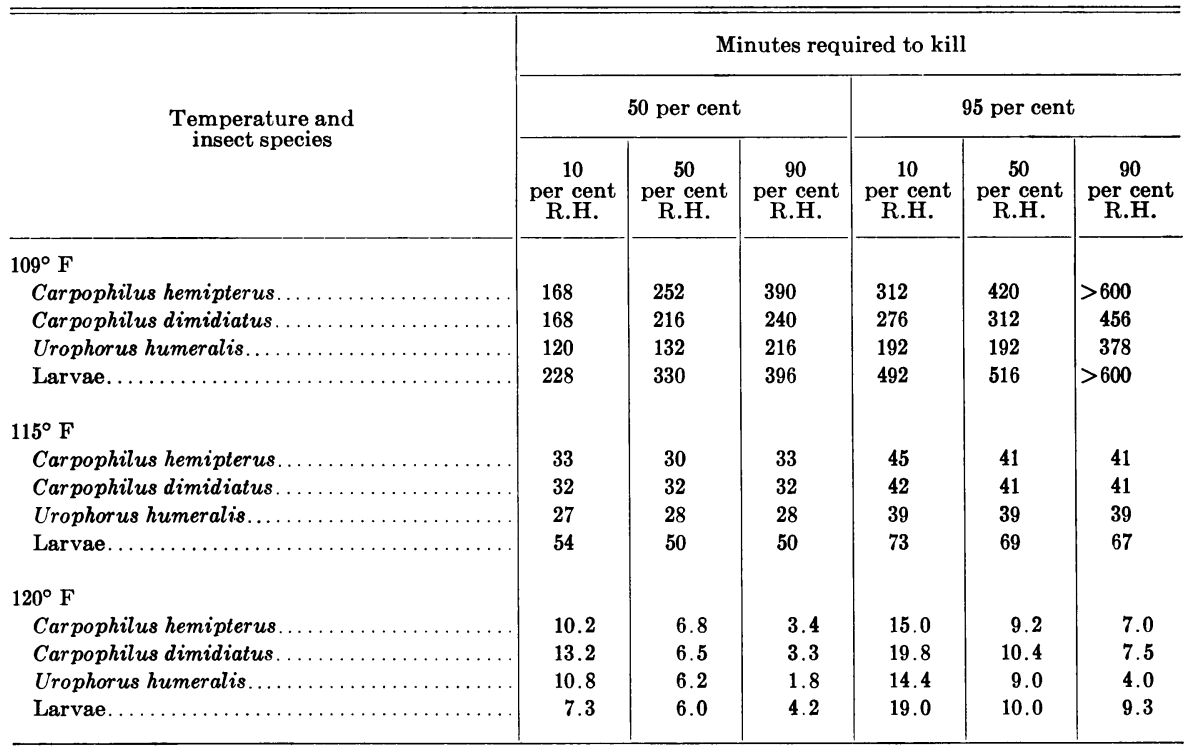

below $115^{\circ} \mathrm{F}$ three species of adult insects and the larvae experimented with were better able to survive in moist than in dry air, because they were unable to conserve water at the lower humidity during the long exposure period and died from a combination of desiccation and heat.

At a temperature of $120^{\circ} \mathrm{F}$ the insects were killed by the effects of heat, as it required a shorter exposure to kill them at 90 per cent relative humidity than at 10 per cent. At $120^{\circ} \mathrm{F}$ they were better able to survive in dry air as they could very likely keep their bodies cool by evaporating water for the short exposure period involved. Desiccation is probably not a factor at these short exposures and at this high temperature.

Since the temperature in the Coachella Valley is above $109^{\circ} \mathrm{F}$ many days during the date-ripening season, it is apparent from the data given in table 5 that, unless the beetles leave the bunches during the hottest part of the day 
to seek a cooler place, they may be killed by the heat. Over a 10-year period (1939-1948), during the months of June, July, August, and September, maximum air temperatures of $106^{\circ} \mathrm{F}$ to $122^{\circ} \mathrm{F}$ occurred. At a temperature of $115^{\circ} \mathrm{F}$ it takes 45 minutes or less to kill 95 per cent of Carpophilus hemipterus, C. dimidiatus, and Urophorus humeralis adults, and at this same temperature it takes approximately 70 minutes to kill 95 per cent of the larvae of $U$. humeralis. It is probable that when maximum air temperatures occur, the temperature within the date bunch, although slightly lower than that of the air, may remain high enough for several hours during the hottest part of the day to be lethal to the adult insects. This may be an explanation why few beetles are found in the dates in the bunches during the hottest part of the day.

Larvae may be found in the dates in the bunches in the hottest months. From table 5 it can be observed that they are better able to survive a temperature of $115^{\circ} \mathrm{F}$ than are the adults. When these high air temperatures occur, the temperature within the dates in the bunches is slightly lower than the air temperature, but it probably approaches the temperature lethal to the larvae at times.

\section{FUMIGATION}

The fumigation of harvested dates is necessary to check the infestation of dried-fruit beetles commonly found in dates in the field in the Coachella Valley. Dates arriving at the packing house are fumigated in chambers with two openings, one to the outside and one to the inside of the packing house. Although it is almost impossible to maintain a packing house entirely free of these insects, fumigation of the dates just before they are taken in for processing arrests the infestation that commonly occurs in the date gardens.

Fumigants used in the past for the fumigation of dates have included carbon disulfide, hydrogen cyanide, ethylene oxide (Nixon, 1951), a mixture of ethylene oxide and carbon dioxide, and methyl bromide. Today methyl bromide is the most commonly used fumigant for date insect pests. Walker and Mitchell (1944), and Armitage and Steinweden (1945), discuss the practice of fumigating dates with methyl bromide. One pound of methyl bromide per 1,000 cubic feet with an exposure of 24 hours at a temperature above $60^{\circ}$ $\mathrm{F}$ is recommended for the control of these pests.

In recent years several new compounds have been tested as fumigants on a wide variety of stored-product insects and soil insects. Two of these, ethylene chlorobromide and ethylene dibromide, are compared with methyl bromide for the control of the eggs, larvae, and adult stages of the nitidulid beetles infesting dates, as well as to determine the survival time following fumigation. Analyses for bromine residues were made on dates fumigated with methyl bromide and ethylene dibromide.

All experimental fumigations were conducted in 100-cubic-foot temperature-controlled fumigation chambers. Circulation was obtained by the use of a 12-inch fan. 
Stages tested included the egg, larva, and adult. All egg-fumigation tests were conducted with 12-16 hour old eggs of Urophorus humeralis on moist blotting paper in open petri dishes. Each group of fumigated eggs had a corresponding control to determine natural mortality. Following fumigation, the eggs were allowed to remain for several hours in the open petri dish to aerate, after which covers were placed on the dishes to prevent desiccation. They were held at a temperature of $80^{\circ} \mathrm{F}$, being checked daily for a period of 6 days, at the end of which time all control eggs had hatched. Life-history studies (table 3 ) have shown that at $80^{\circ} \mathrm{F}$ the eggs of $U$. humeralis hatch within 2 days following deposition; thus it is felt that at the end of a 6-day period any unhatched eggs could be considered dead. Exposures were for a period of 2 hours at temperatures of $70^{\circ}$ and $80^{\circ} \mathrm{F}$.

The larvae and adults of Carpophilus hemipterus, C. dimidiatus, Urophorus humeralis, and Haptoncus luteolus used in these experiments were reared on dates in a small room in the greenhouse insectary at the Citrus Experiment Station. Dates infested with the larvae and adults were placed in $1 / 2$-pint mason jars, the mouth of each jar being covered with cloth netting to allow gas exchange during fumigation. No attempt was made to segregate the various species in the larval stage. The jar containing the infested dates was then placed in the fumigation chamber, and the fumigant applied on a piece of absorbent cloth in a flat container. A fan was allowed to blow across this container to insure evaporation (which occurred within a period of 5 minutes) and an even distribution of the fumigant throughout the fumigation chamber. Exposures were for periods of 2 hours and 6 hours at temperatures of $70^{\circ}$ and $80^{\circ} \mathrm{F}$. After exposure the jars were ventilated by means of a low-pressure air stream, and then held for a period of 3 days, at the end of which mortality counts were made. Three or four tests were generally made at each dosage on different days.

The bromine residue in dates was determined by Dr. W. B. Sinclair, of the Plant Physiology Department of the Citrus Experiment Station, University of California, Riverside, California. In the methyl bromide fumigation of dates, the residual bromine was determined by the method essentially used by Dudley (1939). The bromine residue in the dates fumigated with ethylene dibromide was determined by methods described by Sinclair and Crandall, $1952 a, b$, which consist of hydrolyzing ethylene dibromide with monoethanolamine in the presence of the date fruit and subsequently determining this fumigant as total bromine.

The three fumigants used in these experiments are listed below with their boiling points, molecular weights, and specific gravities:

$\begin{array}{lrcc} & \begin{array}{c}\text { Boiling } \\ \text { point }{ }^{\circ} \mathrm{F}^{*}\end{array} & \begin{array}{c}\text { Molecular } \\ \text { weight* }\end{array} & \begin{array}{c}\text { Specific } \\ \text { gravity* }\end{array} \\ \text { Methyl bromide } & 38 & 94.95 & 1.732 \\ \text { Ethylene chlorobromide } & 224-226 & 143.43 & 1.689 \\ \text { Ethylene dibromide } & 268 & 187.88 & 2.170\end{array}$

* Taken from IIandbook of Chemistry and Physies, 31st Edition, 1949. 


\section{Eggs}

Table 6 shows the results of fumigation tests on exposed eggs of Urophorus humeralis. Ethylene chlorobromide and ethylene dibromide appear more effective than methyl bromide as egg fumigants. At a dosage of $1 / 4$ pound per 1,000 cubic feet at $70^{\circ} \mathrm{F}$ with a 2 -hour exposure, a kill of only 3.4 per cent

TABLE 6

Percentage Kill of Urophorus humeralis Eggs Fumigated with Methyl Bromide, Ethylene Chlorobromide, and Ethylene Dibromide

\begin{tabular}{|c|c|c|c|c|c|c|c|}
\hline \multicolumn{2}{|l|}{ Dosage } & \multicolumn{6}{|c|}{ Percentage kill } \\
\hline \multirow{2}{*}{ Mg per liter } & \multirow{2}{*}{$\begin{array}{c}\text { Pounds } \\
\text { per } \\
1,000 \\
\text { cu. ft. }\end{array}$} & \multicolumn{3}{|c|}{ At $70^{\circ} \mathrm{F}, 2$-hour exposure } & \multicolumn{3}{|c|}{ At $80^{\circ} \mathrm{F}, 2$-hour exposure } \\
\hline & & MB & ECB & EDB & MB & ECB & EDB \\
\hline $8 \ldots \ldots \ldots$ & $1 / 2$ & 4.7 & $\ldots$ & $\ldots$ & 13.8 & $\ldots$ & $\cdots$ \\
\hline 12. . & $3 / 4$ & 35.7 & $\ldots$ & $\ldots$ & 70.7 & $\ldots$ & $\ldots$ \\
\hline 16. & 1 & 80.7 & $\ldots$ & $\ldots$ & 98.4 & $\ldots$ & $\ldots$ \\
\hline $24 \ldots$ & $11 / 2$ & 96.7 & $\cdots$ & $\cdots$ & 100 & & $\cdots$ \\
\hline
\end{tabular}

TABLE 7

Relative EfFectiveness of Methyl Bromide, Ethylene Chlorobromide, and Ethylene Dibromide to a Mixed Culture of Larvae, and Adults of 4 Species of Dried-Fruit BeEtles at Various Temperatures aNd Exposures

\begin{tabular}{|c|c|c|c|c|c|c|}
\hline \multirow{3}{*}{ Temperature and insect species } & \multicolumn{6}{|c|}{ Amount per liter to kill 95 per cent } \\
\hline & \multicolumn{3}{|c|}{ In 2 hours } & \multicolumn{3}{|c|}{-In 6 hours } \\
\hline & MB & ECB & EDB & MB & ECB & EDB \\
\hline $70^{\circ} \mathrm{F}$ & $m g$ & $m g$ & $m g$ & $m g$ & $m g$ & $m g$ \\
\hline Larvae (mixed culture). & 19.0 & 18.0 & 4.0 & 7.0 & 9.0 & $<4.0$ \\
\hline Haptoncus luteolus..... & 14.0 & 10.0 & 6.0 & 6.0 & 4.0 & $<4.0$ \\
\hline Carpophilus hemipterus.. & 15.0 & 8.0 & 5.0 & 7.0 & $<4.0$ & $<4.0$ \\
\hline Carpophilus dimidiatus. & 19.0 & 26.0 & 9.0 & 8.0 & 8.0 & $<4.0$ \\
\hline Urophorus humeralis. . & 16.0 & 17.0 & 5.0 & 7.0 & 7.0 & $<4.0$ \\
\hline $80^{\circ} \mathrm{F}$ & & & & & & \\
\hline Larvae (mixed culture). . & 16.0 & 15.0 & 6.0 & 7.0 & 4.0 & $<4.0$ \\
\hline Haptoncus luteolus..... & 12.0 & 4.0 & $<4.0$ & $<4.0$ & $<4.0$ & $<4.0$ \\
\hline Carpophilus hemipterus. . & 12.0 & 6.0 & 6.0 & $<4.0$ & $<4.0$ & $<4.0$ \\
\hline Carpophilus dimidiatus... & 14.0 & 20.0 & 10.0 & 7.0 & 8.0 & $<4.0$ \\
\hline Urophorus humeralis...... & 12.0 & 12.0 & 4.0 & 6.0 & $<4.0$ & $<4.0$ \\
\hline
\end{tabular}

was obtained with methyl bromide, while under the same conditions a kill of 100 per cent was obtained with both ethylene chlorobromide and ethylene dibromide. The kill with methyl bromide became greater with an increased dosage and a higher temperature, but a dosage of $1 \frac{1}{2}$ pounds per 1,000 cubic feet at $80^{\circ} \mathrm{F}$ was required to obtain 100 per cent kill. In other words, at $80^{\circ} \mathrm{F}$ with a 2-hour exposure it took six times as much methyl bromide to obtain 100 per cent kill as it did ethylene chlorobromide or ethylene dibromide. 


\section{Larvae and Adults}

Table 7 shows the results of fumigation tests on nitidulid larvae and adults in infested dates. Since no attempt was made to separate the larvae by species, the tests were conducted against a mixed group of larvae represented by

\section{TABLE 8}

Relation between Time of Fumigation and Determination of Mortality of a Mixed Culture of Lariate, and Adults of Various Species of Dried-Fruit Beetres at $70^{\circ} \mathrm{F}$ with a 2 -Hour Exposure

\begin{tabular}{|c|c|c|c|c|}
\hline \multirow[b]{2}{*}{ Species } & \multirow{2}{*}{$\begin{array}{c}\text { Hours } \\
\text { between } \\
\text { fumigation } \\
\text { and mortality } \\
\text { determina- } \\
\text { tion }\end{array}$} & \multicolumn{3}{|c|}{ Per cent kill } \\
\hline & & $\begin{array}{c}\text { Methyl } \\
\text { bromide } \\
1 \text { lb.* }\end{array}$ & $\begin{array}{c}\text { Ethylene } \\
\text { dibromide } \\
0.5 \text { lb.* }\end{array}$ & $\begin{array}{c}\text { Ethylene } \\
\text { chlorobromide } \\
0.75 \text { lb.* }\end{array}$ \\
\hline \multirow[t]{5}{*}{ Larvae (mixed culture). . } & 12 & 69.5 & 17.7 & 2.8 \\
\hline & 24 & 81.0 & 40.9 & 21.9 \\
\hline & 48 & 82.0 & 84.6 & 41.4 \\
\hline & 72 & 84.0 & 100 & 84.0 \\
\hline & 96 & 83.2 & 100 & 92.0 \\
\hline \multirow[t]{5}{*}{ Haptoncus luteolus... } & 12 & 100 & 9.1 & 1.6 \\
\hline & 24 & 100 & 41.4 & 57.1 \\
\hline & 48 & 100 & 92.9 & 81.8 \\
\hline & 72 & 100 & 93.8 & 100 \\
\hline & 96 & 100 & 100 & 100 \\
\hline \multirow[t]{5}{*}{ Carpophilus dimidiatus... } & 12 & 88.4 & 3.8 & 6.2 \\
\hline & 24 & 96.0 & 8.0 & 18.9 \\
\hline & 48 & 93.6 & 35.5 & 37.5 \\
\hline & 72 & 88.9 & 88.0 & 84.1 \\
\hline & 96 & 96.4 & 96.0 & 96.0 \\
\hline \multirow[t]{5}{*}{ Carpophilus hemipterus... } & 12 & 95.0 & 60.6 & 38.2 \\
\hline & 24 & 100 & 92.7 & 95.5 \\
\hline & 48 & 100 & 100 & 100 \\
\hline & 72 & 100 & 100 & 100 \\
\hline & 96 & 100 & 100 & 100 \\
\hline \multirow[t]{5}{*}{ Urophorus humeralis. . } & 12 & 100 & 17.0 & 15.2 \\
\hline & 24 & 100 & 76.2 & 75.0 \\
\hline & 48 & 100 & 97.6 & 91.7 \\
\hline & 72 & 100 & 100 & 100 \\
\hline & 96 & 100 & 100 & 100 \\
\hline
\end{tabular}

* All dosages on basis of $1,000 \mathrm{cu} . \mathrm{ft}$. of space.

the four species of adults. In all cases ethylene dibromide proved the most effective fumigant against nitidulid larvae. Except at $80^{\circ}$ and a 6 -hour exposure, it gave a 95 per cent kill with dosages from one fourth to one half those required with methyl bromide and ethylene chlorobromide.

Eggs of Urophorus humeralis are more susceptible to ethylene chlorobromide and ethylene dibromide than are the adults of this species (compare tables 6 and 7). For example, at a 2-hour exposure and a temperature of $70^{\circ}$ F, $4 \mathrm{mg}$ per liter of ethylene chlorobromide and ethylene dibromide gave 100 
per cent kill of the eggs of $U$. humeralis; while it required $5 \mathrm{mg}$ per liter of ethylene dibromide and $17 \mathrm{mg}$ per liter of ethylene chlorobromide to kill 95 per cent of the adult $U$. humeralis at this temperature.

Table 8 gives the results of the relation between the time of fumigation and determination of mortality. At a dosage of 1 pound of methyl bromide per 1,000 cubic feet, it appears that practically all the mortality occurs within 24

TABLE 9

Mean Absorption and Retention of Bromine by Deglet Noor Dates Fumigated with Methyl Bromide and EThylene Dibromide at $74^{\circ} \mathrm{F}$

\begin{tabular}{|c|c|c|c|c|}
\hline Fumigant & $\begin{array}{l}\text { Dosage per } \\
1,000 \text { cu. ft. }\end{array}$ & Exposure & $\begin{array}{l}\text { Time after } \\
\text { fumigation }\end{array}$ & $\begin{array}{l}\text { Bromine } \\
\text { residues as Br } \\
\text { per } 100 \text { gm of of } \\
\text { edible portion }\end{array}$ \\
\hline & pounds & hours & hours & $m g$ \\
\hline Methyl bromide.. & 1 & 2 & $\begin{array}{c}24^{1 / 2} \\
48 \\
168\end{array}$ & $\begin{array}{l}0.80 \\
0.51 \\
0.70 \\
0.68\end{array}$ \\
\hline Methyl bromide. & $3 / 4$ & 6 & $\begin{array}{l}24^{1 / 2} \\
48 \\
168\end{array}$ & $\begin{array}{l}0.98 \\
0.80 \\
0.77 \\
.0 .79\end{array}$ \\
\hline Ethylene dibromide.... & $1 / 4$ & 2 & $\begin{array}{c}24^{1 / 2} \\
48 \\
168\end{array}$ & $\begin{array}{l}0.98 \\
0.86 \\
0.74 \\
0.53\end{array}$ \\
\hline Ethylene dibromide & $3 / 4$ & 2 & $\begin{array}{c}2^{1 / 2} \\
48 \\
168\end{array}$ & $\begin{array}{l}1.68 \\
1.04 \\
0.84 \\
0.74\end{array}$ \\
\hline Ethylene dibromide & $1 / 4$ & 6 & $\begin{array}{c}2^{1 / 2} \\
48 \\
168\end{array}$ & $\begin{array}{l}1.58 \\
1.02 \\
0.92 \\
0.72\end{array}$ \\
\hline
\end{tabular}

hours after fumigation. The greatest increase in mortality following fumigation with ethylene dibromide and ethylene chlorobromide seems to occur in the interval between 24 and 72 hours after fumigation. Some slight additional mortality occurs in the period 72 to 96 hours following fumigation.

Although $1 / 2$ pound of ethylene dibromide and $3 / 4$ pound of ethylene chlorobromide are at least as toxic to the insects tested as 1 pound of methyl bromide per 1,000 cubic feet, it takes a longer period for them to die following fumigation with ethylene chlorobromide and ethylene dibromide than with methyl bromide. It may be possible that with longer exposure periods-12 or 24 hours-the delayed mortality can be overcome. If not, this would be a disadvantage in date fumigation, since many live insects would be introduced into the packing house and might find their way into packaged dates. Al- 
though they will eventually die, their presence meantime is detrimental. Furthermore, it has not been determined if these insects are able to lay eggs during the interval between fumigation and the time death occurs.

The results of the residue determinations are shown in table 9 . With methyl bromide, a greater amount of bromine residue was found in dates exposed to $3 / 4$ pound for 6 hours than in those exposed to 1 pound for 2 hours. The bromine residue dropped only slightly in the first 7 days after fumigation with methyl bromide: at the end of this time the dates still contained from 81 to 85 per cent of that initially absorbed. Armitage and Steinweden (1945) found 20 parts per million of bromine in dates, 12 days after fumigation with methyl bromide at 1 pound per 1,000 cubic feet for 24 hours.

The initial amount of bromine absorbed and retained by dates fumigated at a dosage of $3 / 4$ pound of ethylene dibromide for 2 hours, and $1 / 4$ pound for 6 hours, was much greater than when fumigated with $1 / 4$ pound for 2 hours. There was very little difference in the amount absorbed and retained by dates fumigated with $3 / 4$ pound for 2 hours and $1 / 4$ pound for 6 hours. Bromine content dropped somewhat faster than with methyl bromide: by 7 days after fumigation with ethylene dibromide it had been reduced to from 44 to 54 per cent of that initially absorbed. Hence while more bromine was originally absorbed from ethylene dibromide, the amount a week later was about the same as with methyl bromide, or even lower ( $1 / 4$ pound for 2 hours).

\section{BUNCH TREATMENTS}

Insecticides may be used to reduce beetle infestation by bunch or soil treatments. Laboratory screening of all available insecticides was conducted to determine their initial and residual toxicity to dried-fruit beetles. In these tests the beetles were allowed to walk on 6 -inch squares of cotton cloth, each square impregnated with one of the chemicals being tested. (The various concentrations of insecticide were dissolved in acetone. The cloth squares were then soaked in these solutions, and upon evaporation a finely divided deposit was left on all surfaces of the fabric.) The beetles, after walking on the cloth for a given period of time, were placed in a petri dish, and mortality counts were made at periodic intervals. Residual toxicity of the materials was determined at regular intervals after exposure of the cloth to weathering. Elimination of materials that had no effect on date insects in the laboratory tests narrowed the scope of the field work to those compounds showing the most promise-lindane, chlordane, aldrin, dieldrin, heptachlor, parathion, and malathon.

Continued or residual toxicity is important in the control of dried-fruit beetles in dates because they are constantly moving into the date bunches from outside sources. Therefore any material applied to the dates to control these insects should not only effect a kill at the time of application but also remain toxic for several weeks. Most of the above-listed compounds have an effective residual toxicity. 
Dust applications using $3 / 4$ to 5 per cent of the toxic compound were applied to date bunches 1 to 6 weeks before the first picking. All dusts were applied with hand dusters, and coverage was as even and thorough as possible with this type of applicator, although heavier than would be obtained with conventional power equipment. All bunches, including controls, had been bagged before dust treatments. Control bunches were interspersed among treated bunches. Effectiveness of the treatments was determined by picking treated and untreated dates including culls into cloth trays at 7- or 14-day intervals as they ripened. Fifty of these were transferred immediately to paper bags, which were tied carefully to prevent the escape of insects. The

TABLE 10

Effect of Malathon Dust on Nitidulid Beetles Infesting Deglet Noor Dates

\begin{tabular}{|c|c|c|c|c|c|}
\hline \multirow{2}{*}{ Interval following treatment } & \multicolumn{2}{|c|}{ Control } & \multicolumn{2}{|c|}{5 per cent Malathon Dust } & \multirow{2}{*}{$\begin{array}{c}\text { Per cent } \\
\text { reduction } \\
\text { in } \\
\text { infested } \\
\text { fruit }\end{array}$} \\
\hline & $\begin{array}{c}\text { Alive } \\
\text { insects }\end{array}$ & $\underset{\text { insects }}{\text { Dead }}$ & $\begin{array}{c}\text { Alive } \\
\text { insects }\end{array}$ & $\begin{array}{c}\text { Dead } \\
\text { insects }\end{array}$ & \\
\hline 1 week. & 851 & 35 & 0 & 2,086 & 64.8 \\
\hline 2 weeks. & 2,104 & 0 & 0 & 1,677 & 62.4 \\
\hline 3 weeks. & 541 & 0 & 6 & 623 & 69.6 \\
\hline 4 weeks. & 550 & 14 & 8 & 1,200 & 74.1 \\
\hline 5 weeks. & 1,682 & 0 & 13 & 976 & 81.6 \\
\hline 6 weeks. . & 919 & 12 & 11 & 437 & 90.6 \\
\hline 7 weeks. & 808 & 2 & 17 & 382 & 69.1 \\
\hline 8 weeks. . & 1,746 & 0 & 5 & 2 & 89.0 \\
\hline Total. . & 9,201 & 63 & 60 & 7,383 & \\
\hline
\end{tabular}

samples were then taken to the laboratory, where each date was cut open and examined for evidence of insect infestation. Counts were made of the live and dead adult beetles and larvae. The adults were segregated as to species to determine the relative number of each species present.

Of the materials used in dusting dates in the bunch, lindane, chlordane, aldrin, dieldrin, heptachlor, parathion and malathon were effective in reducing the population of dried-fruit beetles. Parathion, malathon, and dieldrin appeared most effective in these experimental trials.

Chlordane and lindane dusts occasionally imparted an off-flavor to the dates; consequently their experimental use was discontinued.

Because malathon is considerably less toxic to warm-blooded animals than parathion or dieldrin, extensive experiments were conducted during the 1952 season with malathon dusts. Results of these tests are shown in table 10.

It will be noticed that a 5 per cent malathon dust reduced the live beetles in the bunch from over 9,000 to 60 . Up to two weeks following application no live beetles were found in the treated bunches, which tended to remain relatively free from live beetles up to 8 weeks.

There was a reduction of more than 60 per cent in infested fruits in the treated bunches. It should be emphasized that in checking these bunches all 
the cull dates, normally discarded, were included in the samples because of their high degree of spoilage which is correlated with insect infestation. In dates going to the packing house that appeared to be marketable, the number of hidden culls infested in the seed cavity was reduced from 6.3 in the control to 0.75 per cent by the use of a 5 per cent malathon dust. This reduction in hidden culls eliminates the necessity for regrading in the packing house (which adds an additional cost to the grower). When the percentage of hidden culls is excessive, the entire lot of fruit is rejected, as regrading cost would be prohibitive.

It appears that the dust applications should be made at least 3 weeks before picking. The treatment at this time reduces the number of live beetles in the bunch, thus preventing infestations from building up.

TABLE 11

Results of Residue Analyses on Deglet Noor Dates Dusted with 5 Per Cent Malathon Dust

\begin{tabular}{|c|c|c|}
\hline $\begin{array}{l}\text { Interval following application of } \\
5 \text { per cent malathon dust }\end{array}$ & Unwashed & Washed \\
\hline 1 week.... & 3.3 & 0.7 \\
\hline 2 weeks. & 2.0 & 0.6 \\
\hline 3 weeks. . & 1.0 & 0.3 \\
\hline 4 weeks.... & 0.8 & 0.5 \\
\hline 5 weeks. . & 0.04 & 0.1 \\
\hline
\end{tabular}

The use of insecticidal dusts, particularly those toxic to warm-blooded animals, creates a problem of residue. These dusts would be especially objectionable for use on the softer varieties of dates, owing to the difficulty of removing residues from such fruits. Table 11 shows that the residue remaining on Deglet Noor dates dusted with a 5 per cent malathon dust was less than 1 part per million following the washing process in the packing house, although in some cases there was as much as 3 parts per million in the unwashed dates.

Extensive taste tests were conducted on dates dusted with a 5 per cent malathon dust, and in no case could any effect on flavor be detected.

\section{SOIL INSECTICIDES}

Soil treatments have been considered for the control of these beetles, as the larvae pupate in the soil and emerge as adults. The majority of the larvae pupate at a depth of less than 8 inches. It is known that these beetles will fly for several miles in their search for food; therefore any program involving soil treatments would necessitate the treatment of large areas. If a grower applied soil treatments, and his neighbor did not, his dates in the bunch could become infested from the neighbor's untreated garden.

Benzene hexachloride, dieldrin, and chlordane at rates of $1 \frac{1}{2}$ to 2 pounds per acre were dusted onto the surface of the soil and raked in. The treated 


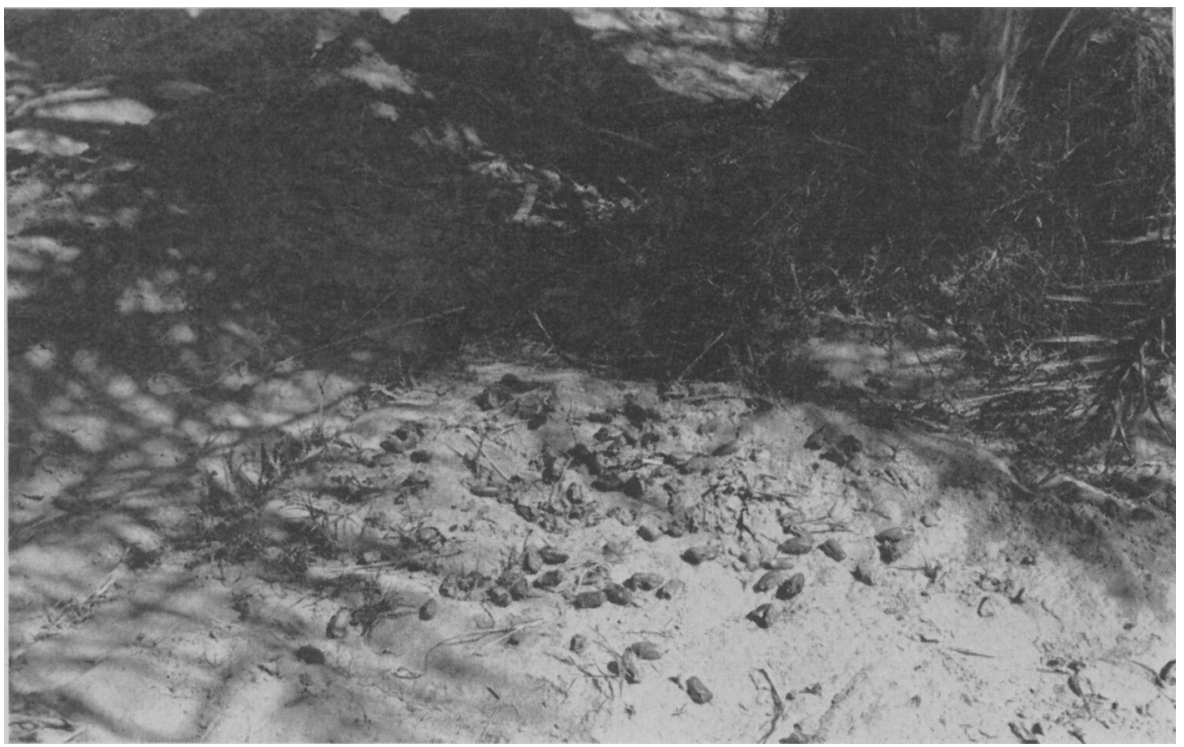

Fig. 4. Date overlay under palm caused by the so-called "June drop."

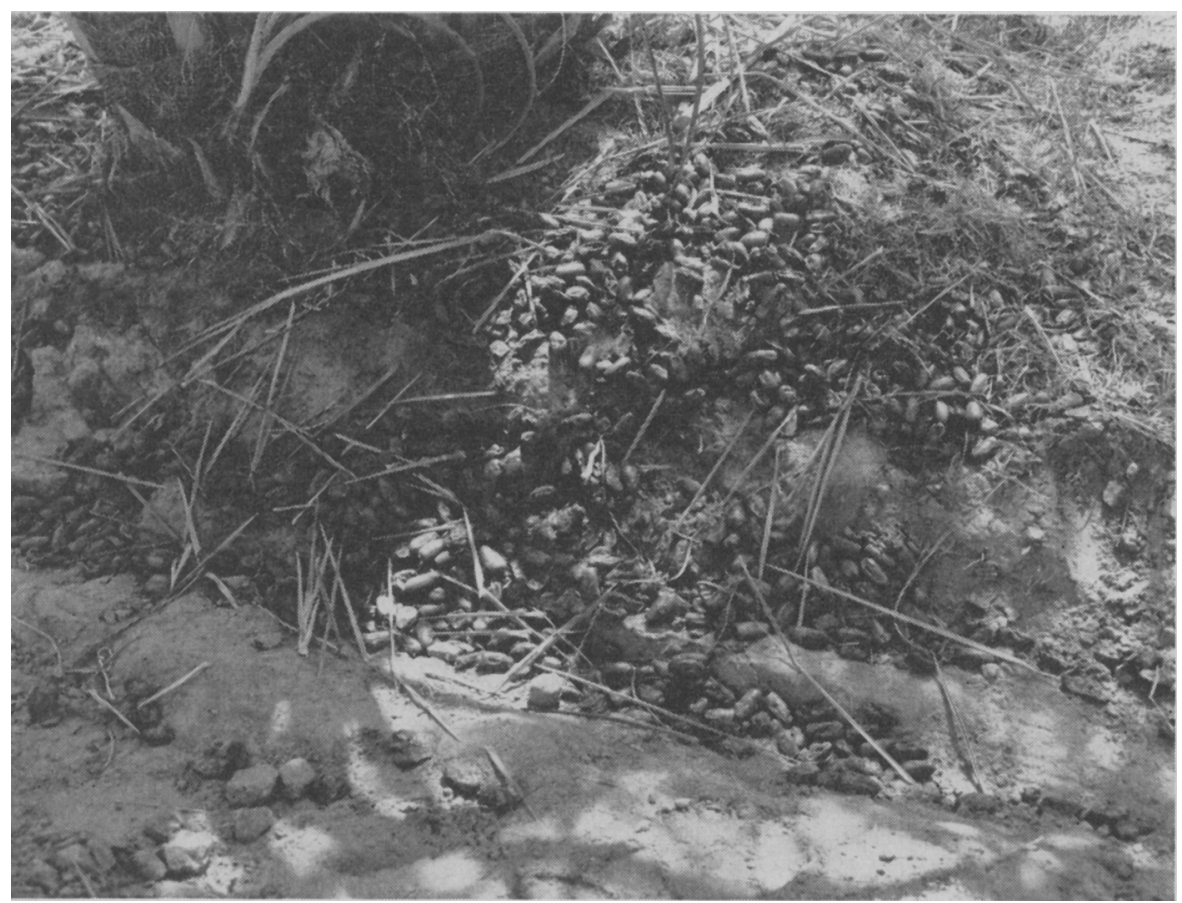

Fig. 5. Date overlay under palm caused by shatter during picking operations. 
surfaces along with the control plots were periodically covered with heavily infested dates, which were allowed to remain on the soil for 1 week. This permitted the mature larvae to enter the soil and pupate. In order to capture the emerging adults, eages were placed over these infested areas. Seventy to 98 per cent of the beetles in the treated plots failed to emerge. One and a half pounds appeared to be as effective as 2 . Dieldrin appeared to have a longer residual action. Indications are that some of these soil treatments may remain effective as long as 1 to 2 months under Coachella Valley conditions.

Soil treatments would involve treating approximately 50 per cent of the soil surface in a date garden; in other words it would be limited to those areas where waste fruit was present because of June drops or picking operations (figs. 4 and 5). Soil samplings have shown that, where there is an abundance of waste dates on the ground, larvae and pupae were plentiful in the soil, whereas if no dates were present on the soil it was difficult to find larvae and pupae.

\section{GARDEN SANITATION}

Probably the principal increase in beetle population in the date gardens occurs in the dates that drop to the ground and remain there to decay. This condition is ideal for the development of the beetles because dates moistened by irrigation water soon begin to ferment and provide favorable feeding conditions, and the beetle larvae which pupate in the soil can pass from the date to the soil with an excellent chance of survival. If all the fallen dates starting with those of the June drop could be picked up so that the beetles could not develop in them it would aid in reducing the population of beetles.

Under field conditions the beetles primarily breed and feed on any material ('ontaining enough sugar to permit fermentation. Observations indicate that the beetle population is low in spring but increases with the appearance of the first June drop. Elimination of all breeding places would contribute toward reducing the insect population. This would not necessarily be restricted to the date garden, but to any place where decaying vegetable matter occurs, such as grapefruit groves, vineyards, and tomato fields. These beetles are primarily scavengers and as such live on decaying melons, citrus fruits, and truck-crop wastes.

\section{ACKNOWLEDGMENTS}

The authors wish to acknowledge the assistance and advice rendered in the course of this work by W. B. Sinclair, W. H. Ewart, F. A. Gunther, P. D. Gerhardt, J. D. Paschke, and R. S. Spriggs. 


\section{LITERATURE CITED}

Armitage, H. M., and John B. Steinweden

1945. The fumigation of California dates with methyl bromide. California Dept. Agr. Bul. $34(3): 101-7$.

BARGER, W. R.

1940. Handling and storing small lots of dates at home. U. S. Dept. Agr. Cir. 553: 12 pp.

BARNES, DWIGHT F., and D. L. LINDGREN

1946. The beetle infestation in dates. Date Growers' Inst. Rept. 23:34-35.

1947. Progress of work on beetle infestation in dates. Date Growers' Inst. Rept. 24:3-4.

BYrd, N. P., and R. E. Blair

1951. California fruit and nut crop acreage estimates as of 1950. California Dept. Agr. Bul. $40(2): 52-79$.

DUDLEY, H. C.

1939. Bromine content of fruits and regetables following fumigation with methyl bromide. Indus. and Engin. Chem., anal. ed. 11(5):259-61.

Essig, E. O.

1915. The dried fruit beetle. Jour. Econ. Ent. 8(4):396-400.

Lindgren, D. L., D. E. Bliss, and Dwight F. BARnes

1948. Insect infestation and fungus spoilage of dates-their relation and control. Date Growers' Inst. Rept. 25:12-17.

Nixon, Roy W., and Walter Reuther.

1947. The effect of enrironmental conditions prior to ripening on maturity and quality of date fruits. Amer. Soc. Hort. Sci. Proc. 49:81-91.

Nixon, Roy W.

1951. Date culture in the United States. U. S. Dept. Agr. Cir. 728:1-57.

OostrHUizen, M. J.

1935. The effect of high temperature on the confused flour beetle. Minnesota Agr. Exp. Sta. Tech. Bul. $107: 1-45$.

Parsons, Carl T.

1943. A revision of nearctic Nitidulidae (Coleoptera). Museum of Comparative Zoology Bul. 92(3) :121-278.

Popenoe, Paul B.

1913. Date growing in the old world and the new. West India Gardens Publishers, Altadena, California. $316 \mathrm{pp}$.

SCHMID', CARL THEODORE

1935. Biological studies on the nitidulid beetles found in pineapple fields. Ann. Ent. Soc. Amer. 28(4) :475-511.

Sinclair, Walton B., and Paul R. Crandall

195:a. Determination of ethylene dibromide in liquid and gas phases by the use of mono. ethanolamine. Jour. Econ. Ent. 45(1) :80-82.

1952b. Methods for determining ethylene chlorobromide and ethylene dibromide. Jour. Econ. Ent. 45(5) : 882-87.

STickney, Fenner

1924. Date palm insects. Date Growers' Inst. Rept. 1:16-17.

Stickney, Fenner S., Dwight F. Barnes, and Perez Simmons

1950. Date palm insects in the United States. U. S. Dept. Agr. Cir. 846. 57 pp.

STREeTs, R. B.

1933. Heart rot of the date palm. Arizona Agr. Exp. Sta. Tech. Bul. 48.

WALKer, JACK, and D. H. Mitcheli.

1944. The fumigation of dates. Date Growers' Inst. Rept. 21:4-6.

WILSON, R. E.

1921. Humidity control by means of sulfuric acid solutions with critical compilation of vapor pressure data. Jour. Indus. and Engin. Chem. 13:326-31. 
The journal Hilgardia is published at irregular intervals, in volumes of about 600 pages. The number of issues per volume varies.

Subscriptions are not sold. The periodical is sent as published only to libraries, or to institutions in foreign countries having publications to offer in exchange.

You may obtain a single copy of any issue free, as long as the supply lasts; please request by volume and issue number from:

\section{Publications Office \\ College of Agriculture \\ Berkeley 4, California}

The limit to nonresidents of California is 10 separate issues on a single order. A list of the issues still available will be sent on request.

In order that the information in our publications may be more intelligible it is sometimes necessary to use trade names of products or equipment rather than complicated descriptive or chemical identifications. In so doing it is unavoidable in some cases that similar products which are on the market under other trade names may not be cited. No endorsement of named products is intended nor is criticism implied of similar products which are not mentioned. 